\title{
Mapping military landscape as a cultural heritage: case study of the Austerlitz/Slavkov battlefield site
} Markéta Šantrůčková1,*, Alena Salašová2, Klára Sokolová², Jozef Sedláček²

\author{
${ }^{1}$ Silva Tarouca Research Institute for Landscape and Ornamental Gardening, Czechia \\ 2 Mendel University in Brno, Faculty of Horticulture, Czechia \\ * Corresponding author: Marketa.Santruckova@vukoz.cz
}

\begin{abstract}
Military landscapes and battlefields are important part of cultural heritage and identity of society. As a part of common social memory, military landscape could be assessed as an associative landscape according UNESCO World Heritage Convention. Before nature and culture heritage could be treasured, it first had to be recognised. Therefore, the paper focuses on identification of historical and cultural values of military landscapes, especially battlefields. Different types of values are discussed and demonstrated on the model area of battlefield Austerlitz/Slavkov near Brno. The battle was held in 1805 and several cultural values are identified there. Identification of cultural historical values is based on detailed analysis of the old and present maps and land cover assessment, study and analysis of archival sources and grey literature and detailed terrain research. Generally, we distinguished several types of values: elements forming the setting of the battlefield; elements tied with the battle (i.e. features and objects that served for purposes of the battle during the fights and are preserved until today); elements created after the battle. Once the associative landscapes are allocated together with their associative patterns, certain values should be given to particular elements in order to secure their protection. Then each planning activity within the site should be given a level of effect on the associative element. This simple matrix implemented in local planning development plans and policies could be a source for rational decision within the associative landscapes.
\end{abstract}

\section{KEYWORDS}

military landscape; battlefield; cultural and historical values; assessment; Austerlitz/Slavkov

Received: 29 October 2020

Accepted: 13 February 2020

Published online: 27 March 2020

Šantrůčková, M., Salašová, A., Sokolová, K., Sedláček, J. (2020): Mapping military landscape as a cultural heritage: Case study of the Austerlitz/Slavkov battlefield site. AUC Geographica 55(1), 66-76

https://doi.org/10.14712/23361980.2020.2

(C) 2020 The Authors. This is an open-access article distributed under the terms of the Creative Commons Attribution License (http://creativecommons.org/licenses/by/4.0). 


\section{Introduction}

Military landscapes could be studied from many perspectives, e.g. social economic conditions and specifics of local and regional identity in military landscapes (Seidl, Chromý 2010), ecological values of (post)military areas (Kopecký, Vojta 2009; Lepková et al. 2018; Bušek, Reif 2017; Lindenmayer et al. 2016), or land use/land cover changes (Havlíček et al. 2018; Skokanová et al. 2017; Gibbes et al. 2017). Military landscapes, especially battlefields, are important part of cultural heritage and identity of society. Battlefield could be regarded as places of memory by state authorities as well as by general public; when it became a place of memory it is usually designed by memorials, museums, etc. As a place of memory, battlefields are joined to (dark) tourism that could initiate the deep investigation of the public sense of the place as well as conservation of the tangible heritage in situ. On the other hand, (dark) tourism industry could endangered the place and its tangible and intangible features by press to development the touristic infrastructure that caused landscape and terrain changes and increase of the built-up areas (Graham, Howard, eds. 2008; Lennon, Foley 2002; Assmannová 2018).

As a part of common social memory, military landscape could be assessed as an associative landscape. The associative cultural landscape is an expression used for categorization of cultural landscapes in terms of World Heritage Convention. In 1992, the World Heritage Convention became the international instrument to recognise and protect cultural landscapes. Cultural landscape is specified there as combined works of nature and humankind, expressing a long and intimate relationship between peoples and their natural environment. Associative cultural landscapes are characteristic by powerful religious, artistic or cultural associations of the natural element rather than material cultural evidence (Fig. 1), which may be insignificant or even absent (Rössler 2006). However, the dark heritage of military landscapes and battlefields often do not fit the scope and purpose of the World Heritage Convention (ICOMOS 2018).
Before nature and culture heritage could be treasured, it first had to be recognised (Lowenthal 2005). Therefore, identification of landscape values is the first step for not only military landscape protection. A complex method of identification and assessment of characteristic landscape appearance was presented by Slámová et al. (2013). Capelo et al. (2011) presented a seventeenth criterion for definition and heritage valuation of landscape study cases which combined cultural and natural values (built heritage, natural biotic heritage, natural abiotic heritage, rarity of the heritage landscape type, antiquity, scientific potential, recreational potential, pedagogic potential, historic record, conservation statue, symbolic importance, coherence degree, conservation degree, aesthetical quality, monumentality, range, craft related value). Methods of identifying historical landscape structures on old maps and aerial photographs occur as frequently as does the assessment of their change in time (Sklenička et al. 2009; Black et al. 1998; Eetvelde, Antrop 2009). Šantrůčková and Weber (2016) focus primary on designed landscapes but the proposed typology of landscape values is universal and could be adapted to military landscapes.

Specifically for military landscapes and battlefields, identification of values composes from several partial features: identification of land cover, land use and terrain in the time of battle, identification of direct traces of the battle, commemorative features and monuments. Land cover for battles from the end of the 18th century till nowadays is documented by old maps, especially, but not only by maps of the First, Second, and Third Military Survey that were made for military reasons (Skaloš et al. 2011; for maps from 20th century see Mackovčin, Jurek 2015), land use for that time is documented in statistical evidence (Šantrůčková, Bendíková 2014; Bendíková et al. 2018). Configuration of relief in battlefield was very important for military purposes; on the other hand, relief could be changed by fortification and artillery fire. For that reasons, studying of relief conditions and identification of human changes in terrain that is possible due to airborne scanning became important source

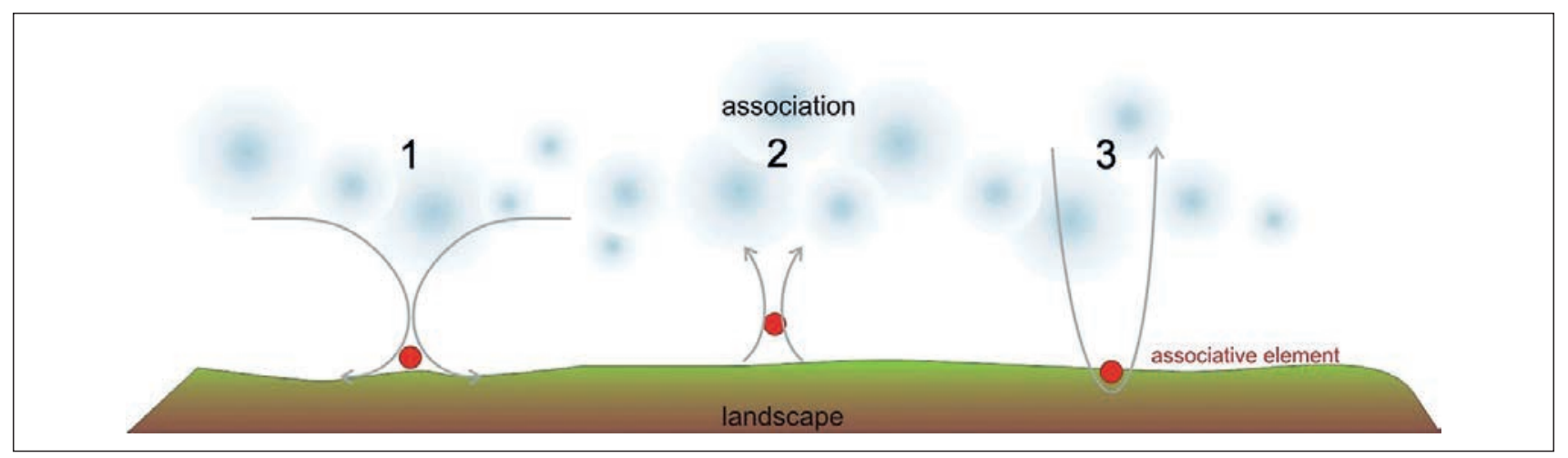

Fig. 1 Schematic diagram showing the process of creation an associative landscape: 1. landscape is influenced/formed by culture; 2. culture is influenced by landscape; 3 . combination of both previous approaches. 


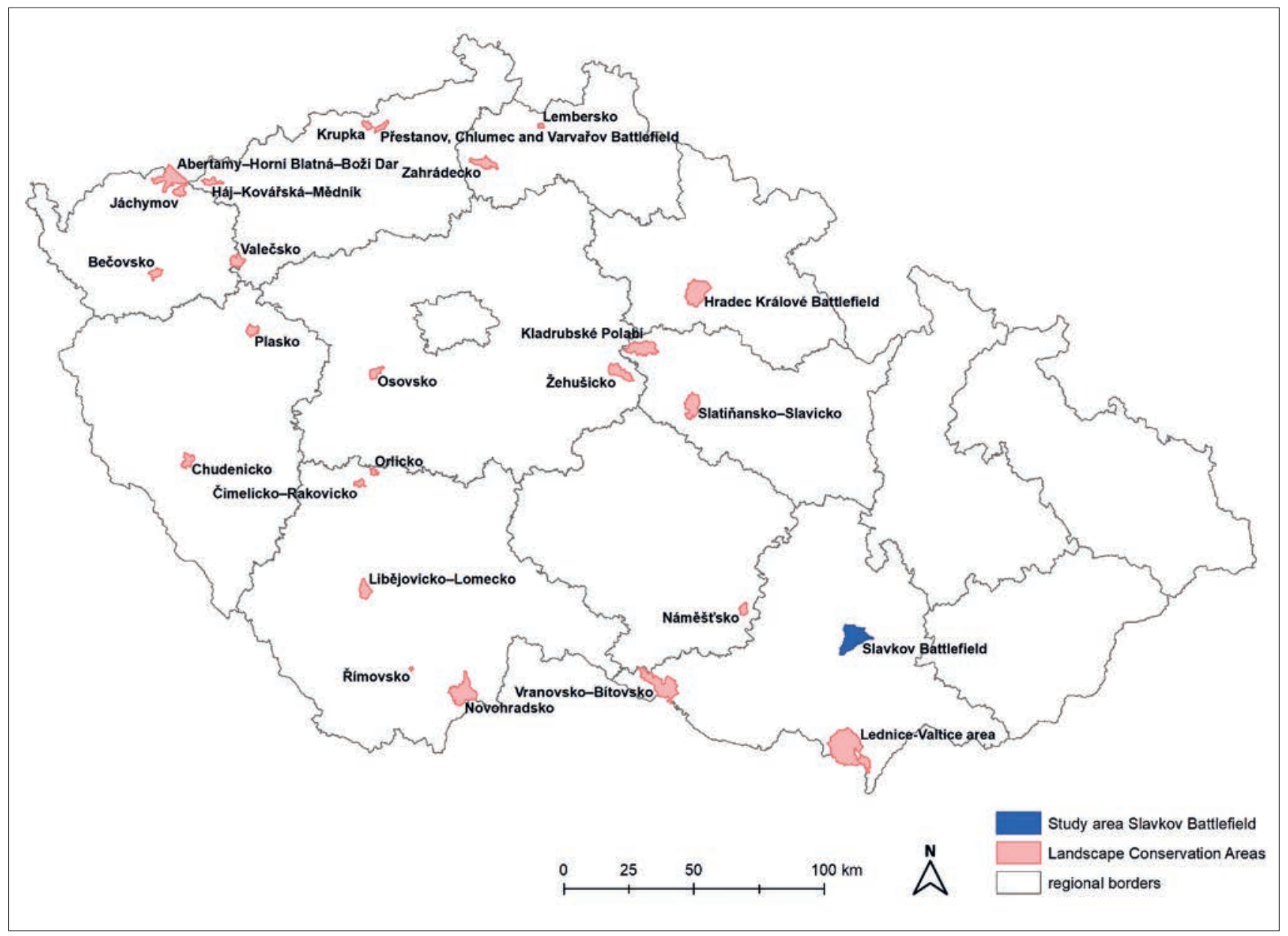

Fig. 2 Landscape Conservation Areas in the Czech Republic.

of information about military landscapes (Maio et al. 2013; Matoušek et al. 2017).

Not only old maps but also other iconographic sources (e.g. engravings) that documented the battle and their landscape are analysed by GIS tool for gain information about landscape values (Janata, Zimová 2016). The informative sources useable for historic landscape assessment are correspondence of the battle's actors, their memories and comments. Other important source of information and part of landscape values themselves are archaeological traces that could be investigated by traditional or distant archaeological methods (Matoušek et al. 2017).

Identification of the cultural historical values of the military landscape could serve as a basis for protection of these landscapes. The complete and participatory protection of areas of historical value including cultural landscapes contrasts with the segregated protection of individual sites used in the past, and is based on the European Landscape Convention (COE 2000), the Convention on Protecting Architectural Heritage (COE 1985) and especially the Convention on Protecting the World Cultural and Natural Heritage (UN 1973) including the related outputs of international expert teams (Mitchell et al. 2009).
Many complete or fragmented historic cultural landscapes have been preserved in the Czech Republic, which require responsible and systematic care. This primarily involves areas protected under the Heritage Act. Selected parts of a cultural landscape may be declared a Conservation Area. A Conservation Area is a settlement formation area or parts of it with fewer cultural monuments, a historical environment or part of the landscape with significant cultural value. The term Landscape Conservation Area is used for protected parts of the landscape. Conservation Areas are declared by the Ministry of Culture of the Czech Republic after consultation with the appropriate regional office. Today, twenty-five Landscape Conservation Areas have been declared in the Czech Republic and three of them are battlefields (Fig. 2), all of them from the 19th century (Austerlitz/Slavkov battlefield 1805, Napoleonic Wars, Chlumec, Přestanov and Varvařov battlefield - 1813, Napoleonic Wars, Hradec Králové battlefield, 1866, Austrian - Prussian War).

The main aim of the papers is to propose a set of cultural and historical landscape features that could be identify in military landscapes, especially in battlefields. The proposed elements should be identifiable in landscape in present and/or in past and are/were tangible cultural heritage of battlefields. 


\section{Material and methods}

\subsection{Study area: Austerlitz/Slavkov battlefield}

The Battlefield of Austerlitz was designated as a Landscape Conservation Area in 1992. The purpose of conservation is tied with a particular event of the Battle of the Three Emperors that took place on December 2, 1805 . The value of the site is represented by physical objects, places and visual connections related to this event. The whole site is a significant commemorative place for the numerous mass graves; some of them have not been even recognised yet (Salašová 2014).

The Battle of Austerlitz (December 2, 1805), also known as the Battle of the Three Emperors, was one of the most important and decisive engagements of the Napoleonic Wars. Widely regarded as the greatest victory achieved by Napoleon, the Grande Armée of France annihilated a larger Russian and Austrian army led by Tsar Alexander I and Emperor Francis II. Because of the near-perfect execution of a calibrated but dangerous plan, the battle is often seen as a tactical masterpiece. Area of the Napoleon's critical manoeuvre called the "Lion's Leap" runs north south across the whole site and extends over several villages (Jiříkovice, Ponětovice, Prace, Hostěrádky - Rešov, Blažovice, Zbýšov, Holubice, Křenovice). Napoleon stroke the Allied troops with an unexpected tactic attack here and predetermined his overall victory in this battle (Fig. 3). Napoleon's victory in Austerlitz

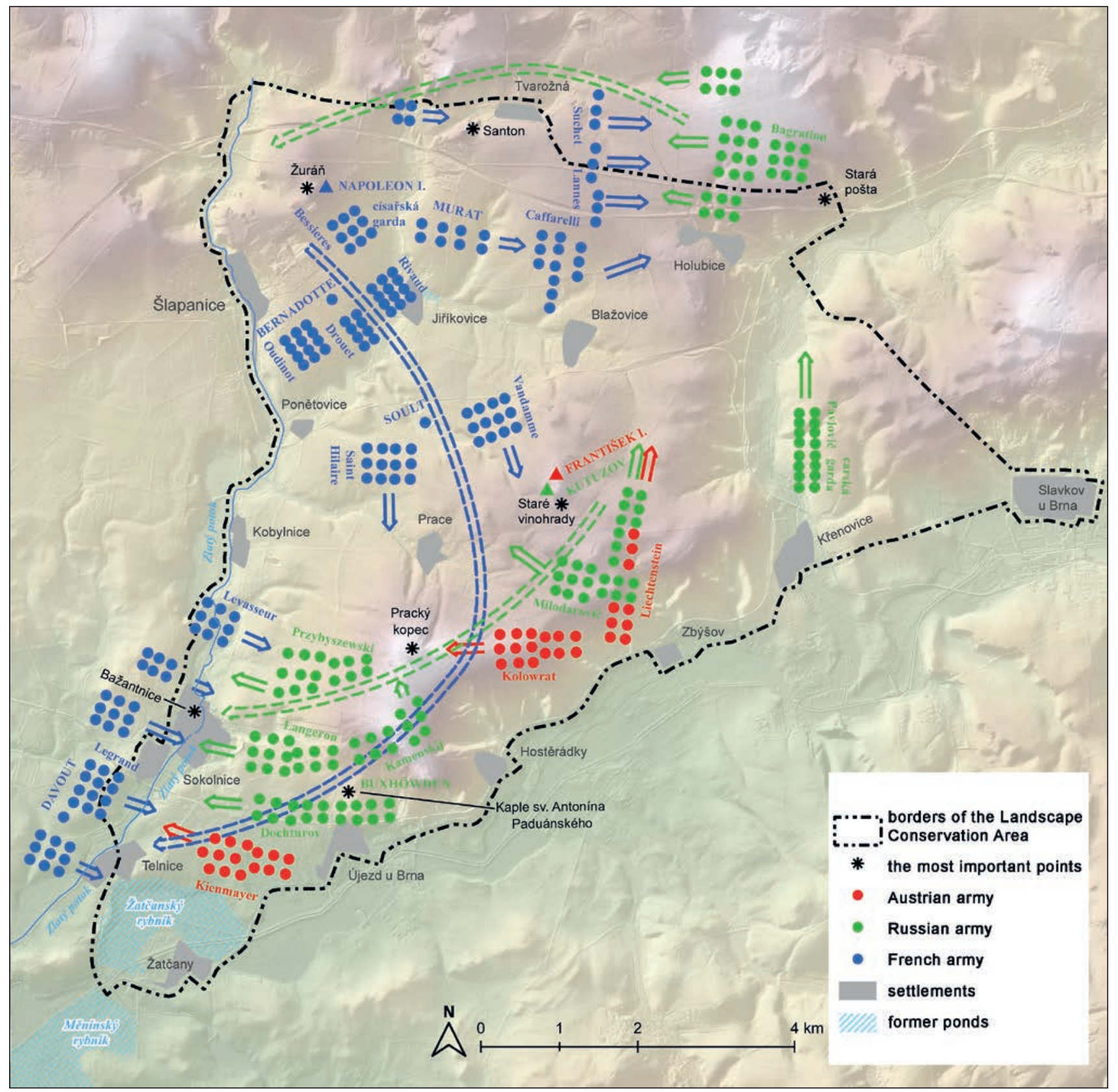

Fig. 3 Layout of the battlefield and positions of the armies before a start of the battle in the morning on December 2, 1805. 
brought the War of the Third Coalition to a rapid end, with the Treaty of Pressburg (Bratislava) signed by the exhausted Austrians later in the month (Kuča et al. 2015; Adams 2005).

The area spreads across 70 square kilometres near a town Slavkov/Austerlitz in the district Brno, Czech Republic. The landscape and especially the topography of the site was a crucial factor for the run of the battle and the eventual victory of French armies led by Napoleon Bonaparte. The landform can be described as relatively flat, slightly undulating (Fig. 4) with four dominant peaks which are Žuráň (287 m a.s.l., a command post of Napoleon), Santon (306 m a.s.l., a strategic point of French troops), Pracký kopec (325 m a.s.l., a point of the final French overturn over Russian and
Austrian armies), Staré Vinohrady near Blažovice (297 m a.s.l., a command post of a Russian general Kutuzov). From these strategic points, the whole battle was commanded.

At the time of the battle (1805), the land was used predominantly for agricultural purposes as arable fields with scarcer high vegetation. The land use pattern was formed by specific long rectangular plots (Salašová et al. 2014). Today, the topography is not changed and the land use is mainly similar - with prevailing agricultural use. The land use pattern though is different as it has been changed and simplified since the beginning of 19 th century. There is also more high vegetation in form of mature trees.

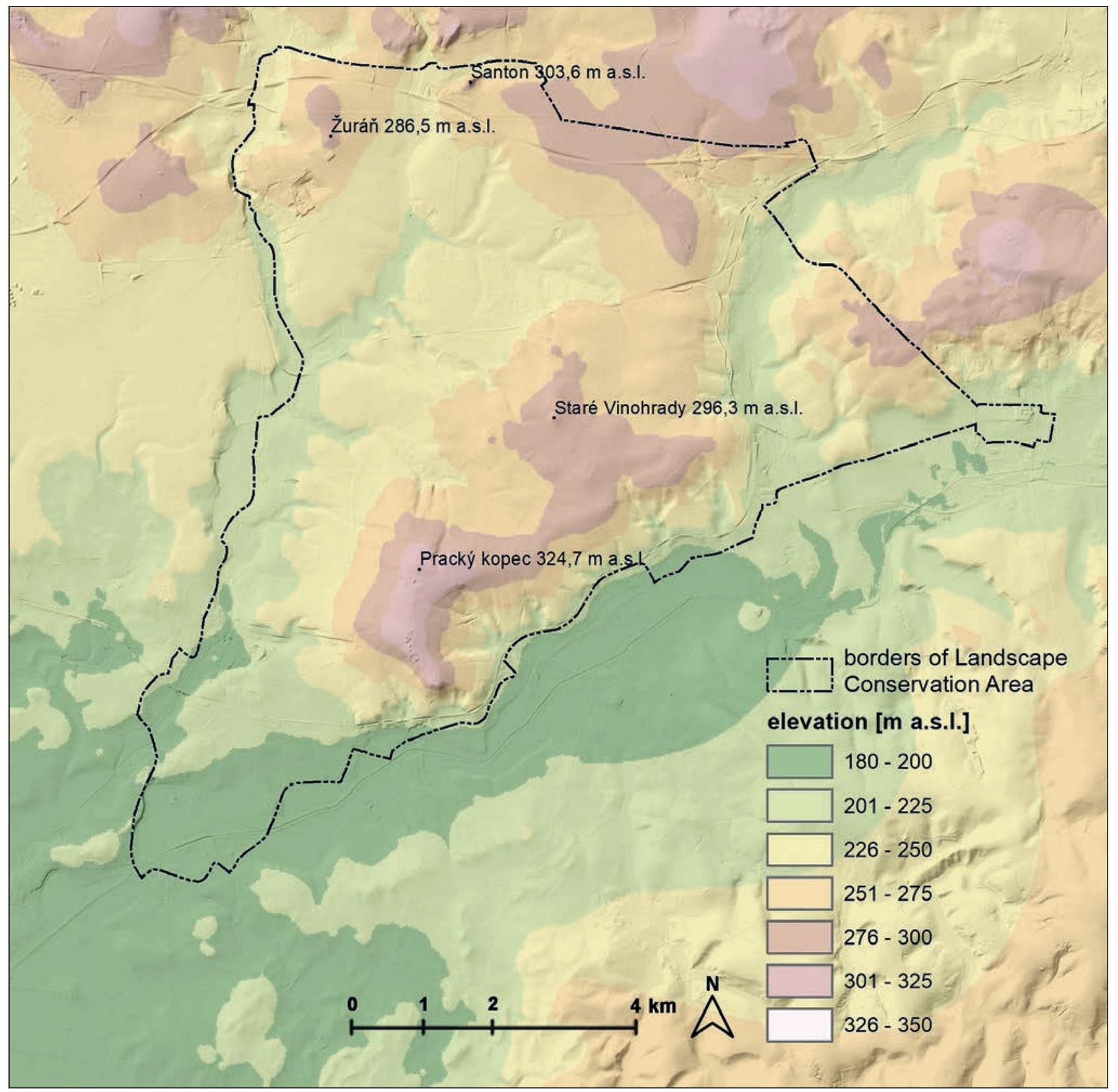

Fig. 4 Local topography of the battlefield at Austerlitz. 


\subsection{Land cover assessment}

The first step, we made, was land cover assessment. The aims of land cover assessment were to investigate land cover in the period of the battle and differences between the past and present state. Cadastral maps of the stable cadastre were used for past state assessment and setting up the former land cover categories of the historical cultural landscape. Stable cadastre maps are very detailed $(1: 2,880)$ and relatively time appropriate (they were made in 1826), so they are the most suitable old maps. Old maps were georeferenced and vectorised manually for all area, twelve land cover categories were identified (Tab. 1).

The present land cover was assessed by the geographic base data of the Czech Republic (ZABAGED) correlated with present orthophoto. ZABAGED consists of 122 types of geographic objects that were modified according the vectorised data of the stable cadastre maps. Lines, namely roads were modified to area objects by the tool "buffer" and widths of new area objects were set up to $6.5 \mathrm{~m}$ for paths, $8.5 \mathrm{~m}$ for roads and $12.5 \mathrm{~m}$ for main roads. The area objects of land cover categories were joined by the tool "union" to one shp file and correlated according the present orthophoto. Then, land cover categories were modified according the situation identified on the stable cadastre maps (Tab. 1). All operations were made in software ArcGIS 10.

\subsection{Mapping of the tangible landscape values in the battlefield}

To fulfil the main aim, we elaborated detailed set of criterions of the landscape features that is aimed to the military landscapes and battlefields (see Tab. 2). Detailed terrain research was carried out for

Tab. 1 Land cover categories on stable cadastre maps and ZABAGED.

\begin{tabular}{|r|l|l|}
\hline No. & $\begin{array}{l}\text { Land cover on stable } \\
\text { cadastre maps }\end{array}$ & Land cover on ZABAGED \\
\hline 1 & high woods & forests \\
\hline 2 & arable land & $\begin{array}{l}\text { arable land and other } \\
\text { non-specified areas }\end{array}$ \\
\hline 3 & permanent grasslands & permanent grasslands \\
\hline 4 & vineyards & vineyards \\
\hline 5 & rocks & open quarries, rocks \\
\hline 6 & low woods & forests with shrubs \\
\hline 7 & water areas & water areas \\
\hline 8 & built-up areas & all types of buildings \\
\hline 9 & orchards & orchards, gardens \\
\hline 10 & roads and paved areas & transport network \\
\hline 11 & ornamental gardens & ornamental gardens and parks \\
\hline 12 & other areas & $\begin{array}{l}\text { dump sites, ruins, airports } \\
\text { surroundings }\end{array}$ \\
\hline
\end{tabular}

Tab. 2 Proposed cultural and historical landscape features for battlefields.

\begin{tabular}{|c|c|c|}
\hline Type & Subtype & Landscape feature \\
\hline \multirow{4}{*}{ Settlement } & \multirow{3}{*}{$\begin{array}{l}\text { Inner structure } \\
\text { of settlements }\end{array}$} & Valuable built-up area \\
\hline & & Real built-up area \\
\hline & & Potential built-up area \\
\hline & Former settlement & Hillfort \\
\hline \multirow{21}{*}{$\begin{array}{l}\text { Valuable } \\
\text { buildings }\end{array}$} & \multirow{3}{*}{$\begin{array}{l}\text { Manor houses } \\
\text { and farms }\end{array}$} & Castle/chateau \\
\hline & & Manor farm \\
\hline & & Fortress \\
\hline & \multirow{3}{*}{ Church buildings } & Church \\
\hline & & Chapel \\
\hline & & Bell tower \\
\hline & \multirow{5}{*}{$\begin{array}{l}\text { Small religious } \\
\text { monuments }\end{array}$} & Wayside shrine \\
\hline & & Cross \\
\hline & & Conciliation Cross \\
\hline & & Memorial \\
\hline & & Statue \\
\hline & \multirow{3}{*}{ Town buildings } & Town hall \\
\hline & & Town house \\
\hline & & Public house \\
\hline & \multirow{2}{*}{ Village buildings } & Tavern \\
\hline & & Blacksmith's workshop \\
\hline & \multirow{2}{*}{ Industrial buildings } & Water mill \\
\hline & & Wind mill \\
\hline & Jewish buildings & Synagogue \\
\hline & \multirow{2}{*}{ Other } & Other building \\
\hline & & Mass grave \\
\hline \multirow{8}{*}{$\begin{array}{l}\text { Historical } \\
\text { cultural } \\
\text { landscape }\end{array}$} & \multirow{2}{*}{$\begin{array}{l}\text { Designed } \\
\text { landscape areas }\end{array}$} & Game park, pheasantry \\
\hline & & Ornamental garden \\
\hline & \multirow{6}{*}{ Former land cover } & Arable land \\
\hline & & Meadows and pastures \\
\hline & & Family garden \\
\hline & & Vineyard \\
\hline & & Forest and scattered vegetation \\
\hline & & Water area \\
\hline \multirow{4}{*}{$\begin{array}{l}\text { Historical } \\
\text { cultural } \\
\text { lines }\end{array}$} & \multirow{2}{*}{$\begin{array}{l}\text { Historical } \\
\text { vegetation lines }\end{array}$} & Two lines alley \\
\hline & & Tree line fruit alley \\
\hline & \multirow{2}{*}{$\begin{array}{l}\text { Historical artificial } \\
\text { lines }\end{array}$} & Historical line construction \\
\hline & & Historical pathway \\
\hline $\begin{array}{l}\text { Historical } \\
\text { point } \\
\text { vegetation }\end{array}$ & Tree & Solitaire tree \\
\hline \multirow{9}{*}{$\begin{array}{l}\text { Spatial } \\
\text { relations }\end{array}$} & View point & View point \\
\hline & Skyline & Local skyline \\
\hline & Landmarks & Landscape landmark \\
\hline & \multirow{3}{*}{$\begin{array}{l}\text { Place of important } \\
\text { event }\end{array}$} & Place of important event \\
\hline & & Battlefield \\
\hline & & Place of the most intensive fights \\
\hline & \multirow{2}{*}{$\begin{array}{l}\text { Compositional } \\
\text { axes }\end{array}$} & Main compositional axe \\
\hline & & Side compositional axe \\
\hline & Scenic roads & Scenic road \\
\hline
\end{tabular}


assessment the present state of identified landscape features. The identified features were drawn to the detailed map of cultural and historical values. The map was produced by software ArcGIS 10 on the geographic base data of the Czech Republic (ZABAGED) in scale $1: 10,000$.

\section{Results}

Two detailed land cover maps were elaborated; one of the historical state in the first half of the 19th century based on the stable cadastre maps (Fig. 5) and second of the present state (Fig. 6). These maps were used for setting up the former land cover categories of the historical cultural landscape. One of the predefined categories in tab. 1 (open quarries, rocks) is not presented in the model area. All identified historical and cultural landscape features in battlefield at Austerlitz were recorded and a detailed analytical map was elaborated (Salašová et al. 2014). The event itself has become an intangible association over the years, however, it is remained by footprints that the battle left behind and which can still be visible or can be experienced. Fig. 7 presents a generalized overview map of tangible cultural landscapes values of the model area.

There are many significant and valuable features on the site, which include historical buildings, historic gardens and castles, tree alleys, skylines, key viewpoints and visual connections. These features are mediums through the story of the battle lives in memories of a current generation.

The features could be categorised as:

1. Features forming the setting of the battlefield - primarily physical topographical features as the main 4 hills, streams and ponds.

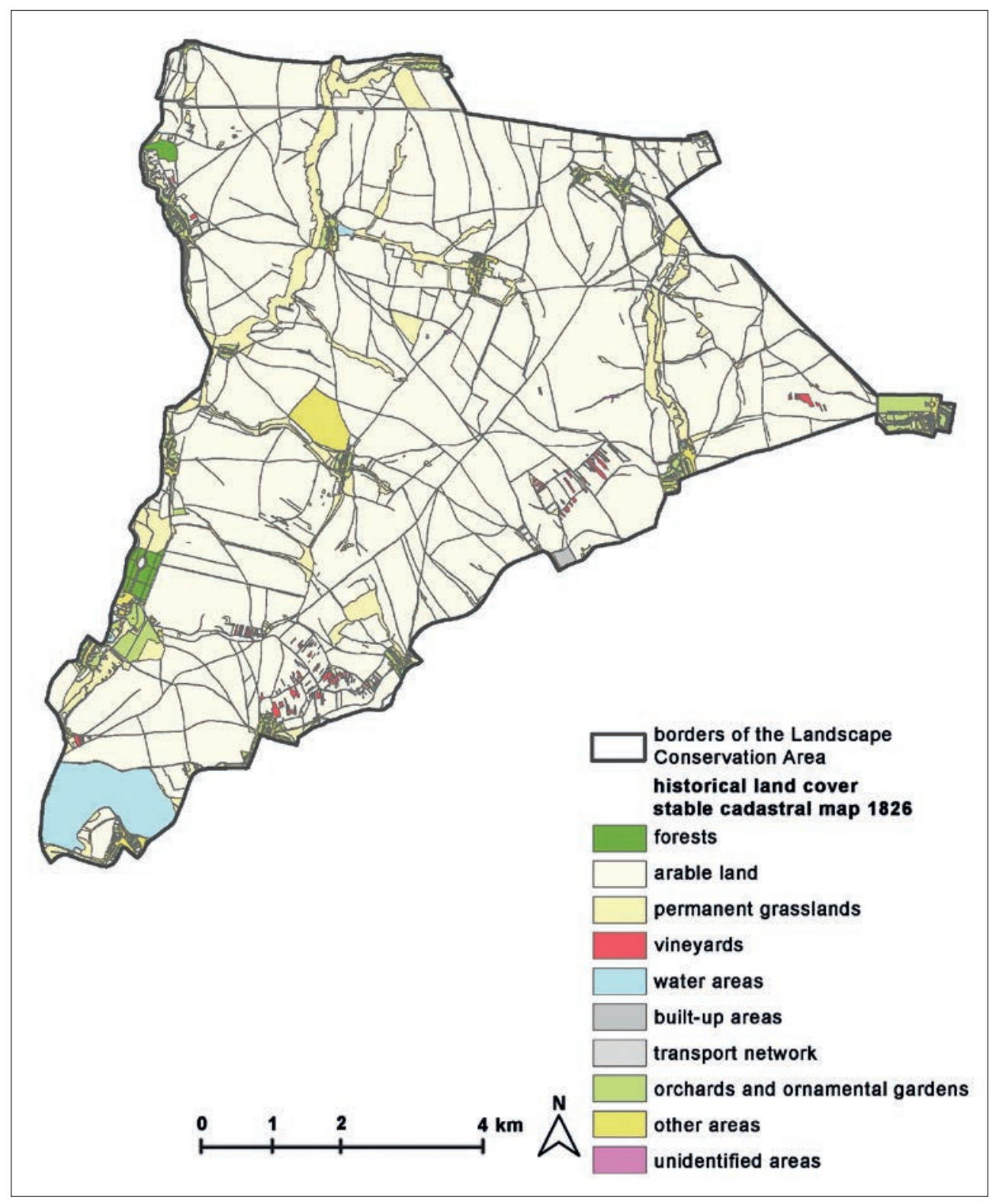

Fig. 5 Historical land cover according the stable cadastral map 1826. 


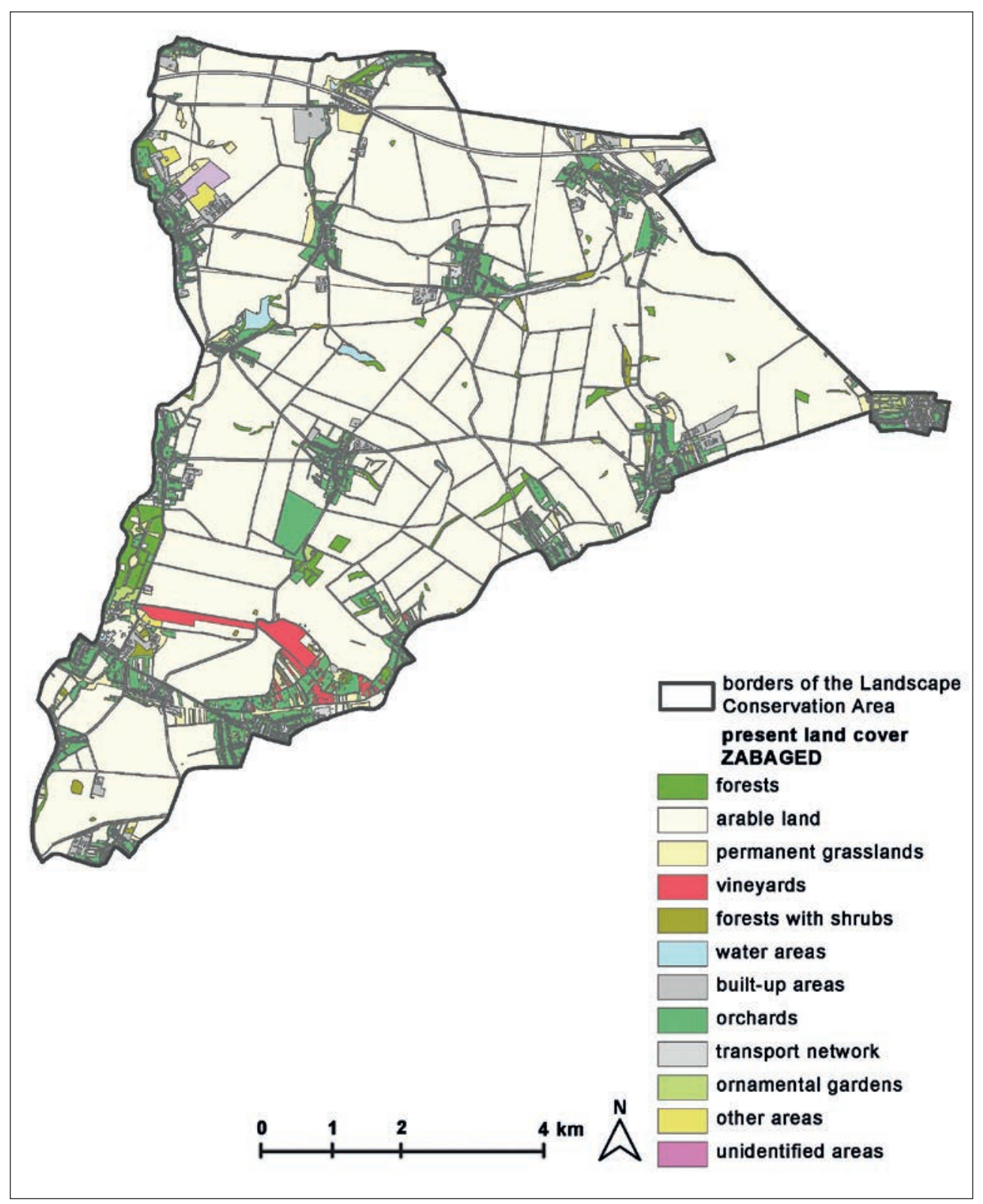

Fig. 6 Present land cover according ZABAGED.

2. Features tied with the battle, i.e. features and objects that served for purposes of the battle during the fights and are preserved until today. They are especially buildings and some minor relicts of groundworks on a side of Santon hill (Stará Pošta, hospitals, churches used as the field hospitals etc.). The sunken field paths are very specific landscape elements commemorate the battle for a long time. They are very often described after a battle as the places fulfil of the killed soldiers and horses' bodies; they are the symbolic elements generally of the war misery.

3. Features created after the battle - especially monuments and memorial objects (Peace Monument Mohyla Míru, numerous other monuments), religious buildings. This includes a whole number of mass graves, which give the site a commemorative sense. Many of the graves have not been discovered or their location might have been forgotten through a span of the years.

These categories could be applied to any associative site or could be used as a guide to prove if the site is of any associative value.

\section{Discussion}

Mapping and evaluating the tangible landscape features that form associative landscape values of the battlefield is essential for landscape protection in the Czech Republic according the Heritage Act (Salašová et al. 2014; Kuča et al. 2015; Šantrưčková, Weber 2016). The Austerlitz/Slavkov battlefield was declared as Landscape Conservation Area in 1992 


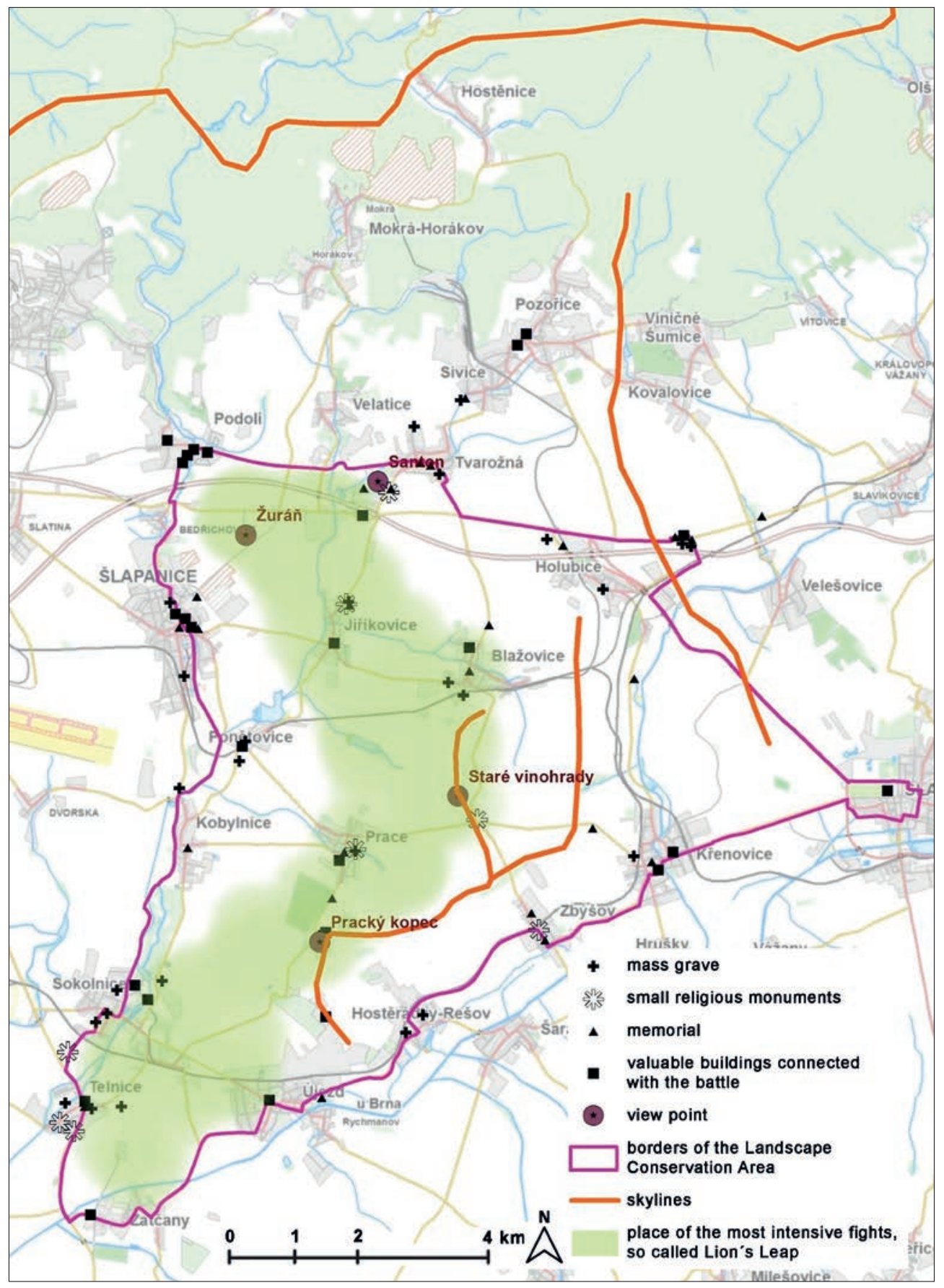

Fig. 7 Map of identified cultural and historical valuable landscape features in battlefield Austerlitz/Slavkov.

for its historical importance, landscape features and composition and landscape quality so the battlefield is legally acknowledge like valuable site.

An intensity of the association tends to fade away with time. There is no doubt that the eye witnesses of the battle of Austerlitz had different memories and feelings about the battle than a generation of people born and living there later. It is not always possible to keep the same level of memories/experience when it is not even necessary. The wounds of the war injuries have been healed and nations participated then in the battle do not continue in the fighting until today. However, there should be some consistent level of knowledge determining creation the right associations in minds of the inhabitants that they may know the value of the site and its protection is their interest (Graham, Howard, eds. 2008; Lennon, Foley 2002; Assmannová 2018).

Different views and opinions on the same associative event may also occur (Graham, Howard, eds. 2008; Assmannová 2018). This may not apply to associative landscapes listed above within the UNESCO list as they usually form a part of national identity and are widely recognised as highly valuable (Rössler 2006). For that reasons, only few sites were listed on the UNESCO list as associative landscape of conflicts 
and death (ICOMOS 2018). With an event as controversial as a war or a battle, different people may keep different attitudes for many decades. Therefore, some local people may be fans of Napoleonic wars and may find the story of the battle thrilling; the others see it as a blood shed which should have been avoided at any cost.

The associative landscapes were not left alone once the event was over. People continue to live in those areas and bring along all that is related to their lifestyle. This includes also local planning for growth of settlements located in the sites. The values of such landscapes may be improved or lowered or even damaged not by another disastrous even such as a war or a battle but by simple planning activities, which minimise effect of appointed associative elements. The different views can affect decision-making processes on the site largely (Graham, Howard, eds. 2008; Lennon, Foley 2002). Moreover, this may be a reason why the Battlefield of Austerlitz does not have any management plan that would unify all the 21 settlements on the site in one systematic approach to the site protection, conservation, and development but only individual mater plans for each settlement. The identification of landscape features could be a basis for a management plan for whole Landscape Conservation Area that would be initiated by the National Heritage Institute.

There are also visitors coming to see the places where the battle took place and with increasing popularity of the site, the pressure and demand of the visiting people on available leisure facilities, accommodation, information centres, parking places or entertainment may cause damage to the values of the site. Many of the cultural historical landscapes deal with this issue and try to find a balance between a strict preservation and making the site attractive for people keen to learn more about its values. Whatever features or attractions they may be, there is always a risk that the supplementary features overshadow the associative elements and overturn the value of the site to an opposite meaning (Lennon, Foley 2002).

Associative values may also be seen as restrictions to a local planning. Local authorities may feel bound within strict barriers that do not allow them to put forward any planning decision that would harm the local associative values (Salašová et al. 2014). This may be a real issue especially when the land is suitable for certain sorts of developments that could bring a great profit to the area, mainly increasing of built-up areas for housing, technical and road infrastructure and tourism industry.

\section{Conclusion}

There is an evident importance of associative landscapes within a human society. They allow to link tangible values, events and ideas with something as specific and unique as a particular piece of landscape and create a valuable connection living in people's minds. They can form a part of national or local identity and be important for many cultural products of the society. Apart from a few associative (and especially military) landscapes inscribed on the World Heritage list there are many local associative landscapes whose value has not been recognised yet.

The recognising process also requires a set of features for identification of associative landscapes. Once the associative landscapes are allocated together with their patterns, certain features should be given to particular elements in order to secure their protection. Then each planning activity within the site should be given a level of effect on the landscape element. This simple matrix implemented in local planning development plans and policies could be a source for rational decision within the associative landscapes.

\section{Acknowledgements}

This research was funded by the Ministry of Culture of the Czech Republic, Programme NAKI II DG16P02M034 Identification and presentation of heritage potential of historic cultural landscapes in the Czech Republic.

\section{References}

Adams, M. (2005): Austerlitz: The battle of the two emperors. History Today 55(12), 30-36.

Assmannová, A. (2018): Prostory vzpomínání. Podoby a proměny kulturní paměti. Praha, Karolinum.

Bendíková, L., Šantrůčková, M., Lipský, Z. (2018): Evaluation of land cover / land use development in selected landscape conservation areas in comparison to non-protected areas. Geografie 123(3), 295-316, https://doi.org/10.37040/geografie2018123030295.

Black, A. E., Strand, E., Wright, R. G., Scott, J. M., Morgan, P., Watson, C. (1998): Land use history at multiple scales: implications for conservation planning. Landscape and Urban Planning 43(1-3), 49-63, https://doi.org /10.1016/S0169-2046(98)00096-6.

Bušek, O., Reif, J. (2017): The potential of military training areas for bird conservation in a central European landscape. Acta Oecologica 84, 34-40, http://dx.doi.org /10.1016/j.actao.2017.08.005.

Capelo, S., Barata, F. T., Mascarenhas, J. M. (2011): Why are cultural landscapes of various values? Thinking about heritage landscape evaluation and monitoring tools. Journal of Landscape Ecology 4(1), 5-17, https://doi.org /10.2478/v10285-012-0030-3.

COE (1985): Convention for the Protection of the Architectural Heritage of Europe, Granada, ETS No. 121. Strasbourg, Council of Europe.

COE (2000): European Landscape Convention, Florence, CETS No. 176. Strasbourg, Council of Europe.

Eetevelde, V. Van, Antrop, M. (2009): Indicators for assessing changing landscape character of cultural 
landscapes in Flanders (Belgium). Land Use Policy 26(4), 901-910, https://doi.org/10.1016/j.landusepol .2008.11.001.

Gibbes, C., Havlick, D. G., Robb, J. R. (2017): Land use and land cover in a transitioning militarized landscape. Journal of Land Use Science 12(2-3), 182-196, https:// doi.org/10.1080/1747423X.2017.1313325.

Graham, B., Howard, P. (eds.) (2008): The Ashgate research companion to heritage and identity. Aldershot Burlington, Ashgate Publishing.

Havlíček, M., Skokanová, H., Dostál, I., Vymazalová, M., Pavelková, R., Petrovič, F. (2018): The consequences of establishing military training areas for land use development-A case study of Libavá, Czech Republic. Land Use Policy 73, 84-94, https://doi.org/10.1016 /j.landusepol.2018.01.039.

Icomos (2018): ICOMOS Discussion pater. Evaluations of World Heritage Nominations related to Sites Associated with Memories of Recent Conflicts. Paris, ICOMOS.

Janata, T., Zimová, R. (2016): Using GIS and methods of digital cartography for analysing battlefield engravings of 17th century. Geoinformatics FCE CTU 15(1), 47-59, https://doi.org/10.14311/gi.15.1.4.

Kopecký, M., Vojta, J. (2009): Land use legacies in postagricultural forests in the Doupovské Mountains, Czech Republic. Applied Vegetation Science 12(2), 251-260, https://doi.org/10.1111/j.1654-109X.2009.01023.x.

Kuča, K. et al. (2015): Krajinné památkové zóny České republiky. Praha, Národní památkový ústav.

Lennon, J., Foley, M. (2002): Dark tourism. The attraction of death and disaster. London - New York, Continuum.

Lepková, B., Horčičková, E., Vojta, J. (2018): Endozoochorous seed dispersal by free-ranging herbivores in an abandoned landscape. Plant Ecology 219(9), 1127-1138, https://doi.org/10.1007/s11258 -018-0864-9.

Lindenmayer, D. B., MacGregor, C., Wood, J., Westgate, M. J., Ikin, K., Foster, C., Ford, F., Zentelis, R. (2016): Bombs, fire and biodiversity: Vertebrate fauna occurrence in areas subject to military training. Biological Conservation 2 04, 276-283, https://doi.org/10.1016/j.biocon.2016 .10 .030 .

Lowenthal, D. (2005): Natural and Cultural Heritage. International Journal of Heritage Studies 11(1), 81-92, https://doi.org/10.1080/13527250500037088.

Mackovčin, P., Jurek, M. (2015): New facts about old maps of the territory of the former Czechoslovakia. Geografie 120(4), 489-506, https://doi.org/10.1016 /j.culher.2012.08.002.

Maio, C. V., Tenenbaum, D. E., Brown, C. J., Mastone, V. T., Gontz, A. M. (2013): Application of geographic information technologies to historical landscape reconstruction and military terrain analysis of an American Revolution Battlefield: Preservation potential of historic lands in urbanized settings, Boston, Massachusetts, USA. Journal of Cultural Heritage 14(4), 317-331, https://doi.org/10.1016/j.culher.2012 .08 .002 .
Matoušek, V., Janata, T., Chlíbec, J., Urbani, R., Zimová, R. (2017): Třebel 1647. A battlefield of the Thirty years' war from the perspective of history, archeology, arthistory, geoinformatics, and ethnology. Praha, Agentura Krigl.

Mitchell, N., Rössler, M., Tricaud, P. M. (2009): World Heritage Cultural Landscapes. A Handbook for Conservation and Management. Paris, World Heritage Centre UNESCO.

Rössler, M. (2006): World Heritage cultural landscapes: A UNESCO flagship programme 1992-2006. Landscape Research 31(4), 333-353, https://doi.org /10.1080/01426390601004210.

Salašová, A., Sedláček, J., Sokolová, K., Trpáková, L., Pacáková, B. (2014): Kulturně historické hodnoty a kompoziční jevy krajinné památkové zóny Území bojiště bitvy u Slavkova - krajinářsko-analytický výkres A. Lednice, Mendelova univerzita v Brně. Zahradnická fakulta.

Seidl, T., Chromý, P. (2010): Problémy integrace marginálního území do regionálního systému. Příklad Vojenského újezdu Boletice. Geografie 110(1), 44-63.

Skaloš, J., Weber, M., Lipský, Z., Trpáková, I., Šantrůčková, M., Uhlířová, L., Kukla, P. (2011): Using old military survey maps and orthophotograph maps to analyse long-term land cover changes - case study (Czech Republic). Applied Geography 31(2), 426-438, https://doi.org /10.1016/j.apgeog.2010.10.004.

Sklenička, P., Molnárová, K., Brabec, E., Kumble, P., Pittnerová, B., Pixová, K., Šálek, M. (2009): Remnants of medieval field patterns in the Czech Republic: Analysis of driving forces behind their disappearance with special attention to the role of hedgerows. Agriculture, Ecosystems and Environment 129(4), 465-473, https:// doi.org/10.1016/j.agee.2008.10.026.

Skokanová, H., Havlíček, M., Klusáček, P., Martinát, S. (2017): Five military training areas - five different trajectories of land cover development? Case studies from the Czech Republic. Geographia Cassoviensis XI (2), 201-213.

Slámová, M., Jančura, P., Daniš, D. (2013): Methods of historical landscape structures identification and implementation into landscape studies. Ekologia (Bratislava) 32(3), 267-276, https://doi.org/10.2478 /eko-2013-0023.

Šantrůčková, M., Bendíková, L. (2014): Assessment of land use changes in landscape conservation areas based on LUCC database. In: Bičík, I. et al. (eds.). Land Use/Cover Changes in Selected Regions in the World. Volume IX. Asahikawa - Prague, IGU-LUCC, 83-93.

Šantrůčková, M., Weber, M. (2016): Identification of Values of the Designed Landscapes: Two Case Studies from the Czech Republic. In: Agnoletti, M., Emanueli, F. (eds.). Biocultural Diversity in Europe. Switzerland, Springer, 487-510, https://doi.org/10.1007 /978-3-319-26315-1_26.

UN (1973): Convention Concerning the Protection of the World Cultural and Natural Heritage. Paris, November 16, 1972. 1037 U.N.T.S. 151, 27 U.S.T. 37, 11 I.L.M. 1358. 